\section{Training in Food Technology}

The Food Group of the Society of Chemical Industry met on February 13, at the London School of Hygiene and Tropical Medicine, to take part in a discussion on "The Training of the Food Technologist", opened by Dr. H. B. Cronshaw, editor of Food Manufacture, the Industrial Chemist and other publications. As Dr. Cronshaw's paper had been circulated before the meeting, he gave a brief sum. mary of the more contentious parts and showed a number of slides illustrating numerous institutions, chiefly in North America, at which research and teaching in food technology are combined to various degrees. The main part of Dr. Cronshaw's paper, however, and that which gave rise to most discussion, contained a plea for the introduction in Great Britain of special post-graduate courses in food technology at suitable universities and colleges. Dr. Cronshaw's paper included a comprehensive and very useful survey of the kind of problems with which the food technologist is likely to be confronted, as well as some ingenious classifications of the type of product with which these technologists have to deal. For this reason alone its publication in full in Food Manufacture will be anticipated with much interest. His main plea, however, was subject to considerable criticism by various members of the Society, par. ticularly on the grounds that it tended to overemphasise the need of specialised technological knowledge in the young post-graduate entering industry, and so to run the risk of supplying him inadequately with the essential scientific outlook. Some of the discussion also directed attention to the importance of considering pre-graduate as well as post-graduate studies, and even of elementary and secondary education.

\section{Museum of the History of Science at Oxford}

ON February 12 Congregation at Oxford unanimously passed the statute which alters the name of the institution housing the Lewis Evans and other collections of scientific instruments to the "Museum of the History of Science, Old Ashmolean Building". The first step towards the full recognition of this institution-hitherto governed by decrees-has thus been taken. The museum is to be administered by the Vice-Chancellor, the Proctors and six others, three of whom will be appointed by the science boards. At the moment there will be no extension of the premises. A decree, however, was also passed assigning the main ground-floor room of the old Ashmolean to the museum at a date not later than 1942. This room, where in the past the New Oxford Dictionary was compiled, and the present upperfloor room, where the collections now are, should be adequate for the museum for many years. It is a pity, however, that this increased accommodation, at the moment badly wanted, cannot be definitely secured earlier, and that the University cannot promise adequate financial support for the staff in charge. It is to be hoped that such help will soon be forthcoming, so that the museum may take a bigger part in the science teaching in Oxford-an oppor- tunity for a generous donor. Congregation expressed themselves very appreciative of the work of Dr. R. T. Gunther, the curator, who not only created the museum single-handed more than ten years ago, but also has since given his services as administrator and teacher for a purely nominal salary.

\section{Pollution at Sea by Discharge of Oil}

IN July last, the British Government, stating that representations had been made to it that the pollution of the coasts of the British Isles by the discharge of oil and oily matter outside the territorial limits by ships was increasing, suggested that the matter be referred for preliminary examination to the Communications and Transit Organisation of the League of Nations, with the view of concluding if possible an international convention. At the last Assembly, this view was further explained by the British representative and it was decided that an initial inquiry should be undertaken. Experts from Denmark, France, Italy, Japan, the United States and Great Britain were invited to Geneva by the chairman of the Advisory and Technical Committee on Com. munications and Transit. These experts agreed that oil pollution caused the destruction of sea-birds, the wings of which become saturated with oil so that they cannot swim, fly or dive; of fish, particularly shellfish, and of the marine grasses which form the staple food of fish and sea-birds. The pollution of sea-beaches by oil results in harm to bathers and depreciation in value of seaside resorts, and constitutes a menace to public health; finally, the accumulation of oil drifting into harbours offers a serious risk of fire. These evils exist to a varying extent in many countries and the object in view is to provide, by international agreement, some means whereby oil-burning and oil-carrying ships may be prevented from polluting, through the discharge of oil and oily mixtures on the high seas, the coasts to which the matter is liable to drift. Some causes of pollution such as collision, or the pouring of oil on to the sea during storm to assist vessels in distress, cannot be prevented, but it is possible by co-operation to guard against voluntary discharge outside territorial limits, and the Committee of Experts recommend that an appropriate international convention should be concluded.

\section{Security of Tenure and Intensive Farming}

THE private bill promoted by the Metropolitan Water Board, which may involve the destruction of Holly Lodge Farm (see Nature of February 2, p. 177), was read a second time in the House of Commons on February 18. Sir A. Boyd-Carpenter moved that an instruction be given to the cormmitteo which is to consider the bill to leave out works on this site, on account of the unique value of the farm as a research centre. After discussion, Sir Hilton Young, Minister of Health, pointed out that he had consulted the Minister of Agriculture on the matter and it was agreed that the appropriate means of dealing with the question was to refer it to a committee of the House. Sir A. Boyd-Carpenter's motion was then by leave withdrawn. In a letter in The Times of 